\title{
Faktor-faktor yang mempengaruhi kenaikan berat badan pada ibu pengguna KB suntik 3 bulan di wilayah kerja Puskesmas Pamboang Kabupaten Majene
}

\author{
Sastrariah $^{1)}$ \\ ${ }^{1)}$ Prodi Diploma Kebidanan STIKes Bina Bangsa, Majene, Sulawesi Barat \\ E-mail: sastrariah@email.co.id
}

\begin{abstract}
Abstrak
Kenaikan berat badan adalah berubahnya ukuran berat, baik bertambah atau berkurang akibat dari konsumsi makanan yang diubah menjadi lemak dan disimpan di bawah kulit. Tujuan dari penelitian ini adalah untuk mengetahui faktor yang mempengaruhi kenaikan berat badan pada ibu pengguna KB suntik 3 bulan Di Wilayah Kerja Puskesmas Pamboang Kecamatan Pamboang Kabupaten Majene.Penelitian ini merupakan penelitian observasional dengan menggunakan metode pendekatan cross sectional study.Populasi dalam penelitian adalah ibu pengguna KB suntik 3 bulan di Wilayah KerjaPuskesmas Pamboang. Sampel dalam penelitian adalah ini sebanyak 55 dengan menggunakan ujifisher's exact test untuk mengetahuifaktor yang mempengaruhi kenaikan berat badan pada ibu pengguna KB suntik 3 bulan di wilayah kerjaPuskesmas Pamboang. Berdasarkan penelitian menunjukkan bahwa ada pengaruh lama penggunaan KB suntik 3 bulan dengan kenaikan berat badan pada ibu pengguna KB suntik 3 bulan nilai $p=0,000<\alpha=$ 0,05 . Ada pengaruh asupan kalori dengan kenaikan berat badan pada ibu pengguna KB suntik 3 bulan nilai $p=0,006$ $<\alpha=0,05$. Tidak ada pengaruh aktivitas fisik dengan kenaikan berat badan pada ibu pengguna KB suntik 3 bulannilai $p=$ $0,188>\alpha=0,05$. Sehingga dapat disimpulkan bahwa pengaruh lama penggunan merupakan factor risiko terjadinya kenaikan berat badan pada ibu pengguna KB suntik 3 bulan, asupan kalori bukan merupakan faktor risiko terjadinya kenaikan berat badan pada ibu pengguna $\mathrm{KB}$ suntik 3 bulan, tidak ada pengaruh aktivitas fisik dengan kenaikan berat badan pada ibu pengguna KB suntik 3 bulan. Disarankan pada ibu sebaiknya selalu berkonsultasi kepada petugas kesehatan.
\end{abstract}

Kata kunci : Aktivitas Fisik, Asupan Kalori, Kenaikan Berat Badan, Lama Penggunaan KB suntik 3 bulan

\begin{abstract}
Weight gain is changing the size of the weight, both increasing or decreasing due to consumption of foods that are converted into fat and stored under the skin. The purpose of this study was to determine the factors that influence weight gain in women using 3 months injection KB in the Pamboang Community Health Center Pamboang District Majene District. This study was an observational study using the cross sectional study method. Population in the study were mothers of KB users. 3 months injection in the Pamboang Public Health Center. The sample in this study was 55 using the tester's exact test to find out the factors that affected the increase in body weight in the users of the 3-month injection KB family in the work area of Pamboang Health Center. Based on the research, it was shown that there was an effect of the duration of 3 months injection $K B$ use with the increase in body weight in the 3-month injectable birth control user mothers $p$ value $=0,000<\alpha=0.05$. There is an effect of caloric intake with increasing body weight in users of 3-month injection KB users with a value of $p=0.006<\alpha=0.05$. There was no effect of physical activity on increasing body weight in users of 3-month injectable birth control $(K B) p=0.188>\alpha=0.05$. So it can be concluded that the long influence of the use is a risk factor for increasing weight in 3 months injection contraceptive mothers, caloric intake is not a risk factor for increasing body weight for 3-month injectable birth control mothers, there is no effect of physical activity on weight gain in mother of 3 month family planning injection. It is recommended that mothers should always consult with health workers.
\end{abstract}

Keywords : Physical Activity, Calorie Intake, Increase Body Weight, Length of Use of 3-month injection KB 


\section{Pendahuluan}

Wanita yang menggunakan kontrasepsi Depot Medroxy Progesterone Acetate (DMPA) atau dikenal dengan $\mathrm{KB}$ suntik tiga bulan, rata-rata mengalami peningkatan berat badan sebanyak 11 pon atau 5,5 kilogram, dan mengalami peningkatan lemak tubuh sebanyak $3,4 \%$ dalam waktu tiga tahun pemakaian, berdasarkan penelitian yang dilakukan oleh University of Texas Medical Branch (UTMB) (Mansjoer, 2003). Sedangkan pada kontrasepsi suntik bulanan efek samping terhadap berat badan sangatlah ringan, umumnya pertambahan berat badan sedikit (Hartanto, 2003).

Berat badan bertambah atau turun beberapa kilogram dalam beberapa bulan setelah pemakaian suntikan KB (Suratun, 2008). Perubahan berat badan kemungkinan disebabkan karena hormon progesteron mempermudah perubahan gula dan karbohidrat menjadi lemak, sehingga lemak banyak yang bertumpuk di bawah kulit dan bukan merupakan karena penimbunan cairan tubuh. Selain itu, DMPA merangsang pusat pengendali nafsu makan di hipotalamus yang dapat menyebabkan akseptor makan lebih banyak dari biasanya akibatnya pemakaian suntikan dapat menyebabkan berat badan bertambah (Hartanto, 2009).

Teori yang dikemukakan oleh Hartanto (2004) bahwa dari pemakaian kontrasepsi suntik dalam jangka waktu yang lama dapat menyebabkan kenaikan berat badan. Umumnya penambahan berat badan tidak terlalu besar, bervariasi antara kurang dari satu kilogram sampai lima kilogram dalam tahun pertama. Karena adanya kandungan hormon progesteron yang merangsang pusat pengendali nafsu makan di hipotalamus yang dapat menyebabkan nafsu makan bertambah dan apabila pemakaian dosis yang tinggi atau berlebih karena dapat merangsang pusat pengendali nafsu makan di hipotalamus yang menyebabkan akseptor makan lebih banyak dari biasanya.

\section{Metode}

Jenis penelitian yang digunakan dalam penelitian ini adalah jenis penelitian observasionaldengan pendekatan croos sectional study. Variabel dependen dalam penelitian ini adalah kenaikan berat badan pada ibu pengguna KB suntik 3 bulan dan variable independen adalah asupan kalori, lama penggunaan $\mathrm{KB}$ suntik 3 bulan dan aktivitas fisik dilakukan pengamatan secara bersamaan.

Populasi dalam penelitian ini adalah semua ibu yang menggunakan KB suntik 3 bulan yang tercatat di Puskesmas Pamboang tahun 2016,yaitusebanyak 121 ibu pengguna KB suntik 3 bulan. Teknik pengambilan sampel menggunakan teknik purposive sampling. Kriteria inklusi yaitu bersedia jadi responden, berdomisili di wilayah kerja Puskesmas Pamboang, berkomunikasi dengan baik.

\section{Hasil}

\section{Analisis Univariat}

Berdasarkan hasil penelitian bahwa dari 55 responden paling banyak pada kategori umur 26-28 tahun sebanyak 21 responden $(38,18 \%)$, dan responden umur yang paling sedikit pada kateogori umur 20-22 tahun sebanyak 1 orang $(1.82 \%)$. Dari 55 responden diperoleh jumlah responden yang paling banyak adalah yang mengalami kenaikan berat badan sebanyak 44 orang $(80 \%)$ dan yang paling sedikit adalah yang tidak mengalami kenaikan berat badan sebanyak 11 Orang (20\%).

Berdasarkan hasil penelitian menunjukan bahwa dari 55 responden diperoleh jumlah responden yang paling banyak adalah yang lama menggunakan KB suntik 3 bulan sebanyak 44 orang $(80 \%)$ dan yang paling sedikit adalah yang tidak lama menggunakan KB suntik 3 bulan sebanyak 11 orang ( $20 \%$ ). Dari 55 responden terdapat 52 orang $(94.5 \%)$ dengan asupan kalori yang cukup sedangkan asupan kalori kurang sebanyak 3 orang 
(5.5\%). Hasil penelitian menunjukan bahwa dari 55 responden terdapat 47 orang $(85,5 \%)$ dengan aktivitas fisik ringan sedangkan Aktivitas fisik sedang sebanyak 15 orang $(15,5 \%)$.

\section{Analisis Bivariat}

Berdasarkan hasil penelitian dapat diketahui bahwa lama penggunaan $\mathrm{KB}$ suntik 3 bulan pada kategori lama yang mengalami kenaikan berat badan sebanyak $43(97,7 \%)$ dan yang tidak mengalami kenaikan berat badan sebanyak $1(9,1 \%)$. Sedangkan pada kategori tidak lama yang mengalami kenaikan berat sebanyak $1(9,1 \%)$ dan yang tidak mengalami kenaikan berat badan sebanyak 10 (90,9\%). Berdasarkan hasil Uji fisher's exact test diperoleh nilai $\mathrm{P}$ 0.000. Sedangkan nilai $\alpha$ sebesar 0.05 ini menandakan bahwa $\mathrm{P}<\alpha$. Berarti $0.000<0.05$. Yang berarti $\mathrm{Ha}$ diterima atau ada pengaruh signifikan antara lama penggunaan alat suntik $\mathrm{KB}$ terhadap Kenaikan Berat badan.

Adanya nilai koefisien kontingengsi pada hasil uji fisher's exact test sebesar $\mathrm{r}=0.663$ berarti pengaruh lama penggunaan $\mathrm{KB}$ suntik 3 bulan terhadap kenaikan berat badan di kategorikan kuat (0.60-0.799). Dan besar kontribusi terhadap kenaikan berat badan di dapatkan KP $=0.663^{2} \times 100$ diperoleh sebesar $43,9 \%$. Ini menunjukan bahwa lama penggunaan alat suntik KB terhadap kenaikan berat badan sebesar $43,9 \%$ dan sisanya $56,9 \%$ ditentukan oleh variabel lain.

Berdasarkan hasil uji fisher's exact test didapatkan Nilai OR $430>1$ yang berarti bahwa faktor lama penggunaan KB suntik 3 bulan merupakan faktor risiko dengan asosiasi positif yang artinya bahwa ibu pengguna $\mathrm{KB}$ suntik 3 bulan yang lama menggunakan $\mathrm{KB}$ suntik 3 bulan 430 kali berisiko mengalami kenaikan berat badan dibandingkan dengan ibu yang tidak lama menggunakan KB suntik 3 bulan.

Diketahui bahwa asupan kalori pada kategori cukup yang mengalami kenaikan berat badan
$44(84,6 \%)$ dan yang tidak mengalami kenaikan berat badan sebanyak $8(15,4 \%)$ dan pada asupan kalori kategori kurang yang mengalami kenaikan berat badan $0(0,0 \%)$ dan yang tidak mengalami kenaikan berat badan sebanyk 3 (100\%). Berdasarkan hasil Uji fisher's exact test diperoleh nilai P 0.000. Sedangkan nilai $\alpha$ sebesar 0.05 ini menandakan bahwa $\mathrm{P}<\alpha$. Berarti $0.006<$ 0.05.yang berarti $\mathrm{Ha}$ diterima atau ada pengaruh signifikan asupan kalori dengan kenaikan berat badan pada ibu pengguna $\mathrm{KB}$ suntik 3 bulan.

Adanya nilai koefisien kontigengsi pada hasil uji fisher's exact test sebesar $\mathrm{r}=0.433$ berarti ada pengaruh asupan kalori terhadap kenaikan berat badan di kategorikan cukup kuat (0.400.599). dan besar kontribusi terhadap kenaikan berat badan di dapatkan $\mathrm{KP}=0.433^{2}$ x 100 diperoleh sebesar 18,7\%. Hal ini menunjukkan bahwa asupan kalori terhadap kenaikan berat badan sebesar $18,7 \%$ dan sisanya $81,3 \%$ di tentukan oleh variabel lain. Berdasarkan hasil uji fisher's exact test didapatkan Nilai OR $0,154<1$ bukan merupakan faktor risiko.

Diketahui bahwa aktivitas fisik kategori ringan yang mengalami kenaikan berat badan sebanyak $36 \quad(76,6 \%)$ dan yang tidak mengalami kenaikan berat badan sebanyak $11(23,4 \%)$. Sedangkan pada katogori sedang yang mengalami kenaikan berat badan sebanyak $8 \quad(100 \%)$ dan yang tidak mengalami kenaikan berat badan $0(0,0 \%)$ Berdasarkan hasil Uji fisher's exact test diperoleh nilai $\mathrm{P} 0,188$ sedangkan nilai $\alpha$ sebesar 0.05 ini menandakan bahwa $\mathrm{P}>\alpha$. Berarti $0.188>0.05$. Yang berarti Ho diterima dan Ha ditolak yang menyatakan bahwa tidak ada pengaruh signifikan antara aktivitas fisik dengan kenaikan berat badan pada ibu pengguna KB suntik 3 bulan. 


\section{Pembahasan}

KB Suntik 3 bulan, adalah jenis Suntikan KB yang mengandung hormon Depo Medroxy Progesterone Acetate (hormon progestin) dengan volume $150 \mathrm{mg}$. Alat kontrasepsi ini diberikan setiap 3 bulan atau 12 Minggu. Suntikan pertama diberikan 7 hari pertama saat periode menstruasi, atau 6 minggu setelah persalinan. Jenis Suntikan KB ini ada yang dikemas dalam cairan $1 \mathrm{ml}$ atau $3 \mathrm{ml}$.

Progestin adalah hormon yang serupa dengan progesteron, yaitu hormon yang diproduksi ovarium. Progestin dalam suntik KB 3 bulan bekerja dengan menghentikan pelepasan sel telur ke dalam rahim sehingga mencegah terjadinya pembuahan. Selain itu, hormon ini juga mencegah sperma untuk mencapai sel telur dengan menebalkan cairan vagina dan mencegah pertumbuhan janin dengan menipiskan dinding rahim.

Hormon pada KB suntik 3 Bulan memicu reaksi lapar di hipotalamus sehingga menyebabkan pengguna kontrasepsi hormon tersebut lebih sering makan, hal ini memicu penambahan berat badan. Jika mengalami masalah dengan hal ini, baiknya hentikan dan beralih pada kontrasepsi non hormonal. Hasil penelitian pada ibu pengguna KB suntik 3 bulan di wilayah kerja Puskesmas Pamboang Kecamatan Pamboang rata-rata mengalami kenaikan berat badan. Rata-rata ibu pengguna $\mathrm{KB}$ suntik 3 bulan mengalami kenaikan berat badan yang disebabkan adanya hormone progesterone yang mengakibatkan bertambahnya nafsu makan pada ibu pengguna KB suntik 3 bulan.

Penggunaan kontrasepsi suntik DMPA (KB suntik 3 bulan) merupakan salah satu faktor pendukung terjadinya peningkatan berat badan karena kontrasepsi DMPA mengandung hormonal progesteron yang akan mempengaruhi pusat pengendalian nafsu makan, dengan menjadi akseptor suntik DMPA maka biasanya akseptor akan mengonsumsi makan lebih banyak dari biasanya.

Berdasarkan hasil uji fisher's exact test di peroleh hasil ada pengaruh antara lama penggunaan $\mathrm{KB}$ suntik 3 bulan dengan kenaikan berat badan pada ibu pengguna $\mathrm{KB}$ suntik 3 bulan dengan kekuatan pengaruh masuk dalam kategori kuat,lama penggunaan memberikan kontribusi terhadap kenaikan berat badan pada ibu pengguna KB suntik 3 bulan di wilayah kerja Puskesmas Pamboang Kecamatan pamboang sebesar $43.9 \%$. Hal ini menunjukkan bahwa lama penggunaan $\mathrm{KB}$ suntik 3 bulan mempunyai peranan yang cukup besar terhadap kenaikan berat badan pada ibu pengguna KB suntik 3 bulan. Sehingga untuk menurunkan berat badan sangat sulit karena semakin lama penggunaan $\mathrm{KB}$ suntik 3 bulan maka semakin naik berat badan pada ibu pengguna KB suntik 3 bulan.

Hal ini didukung oleh teori Nault (2013) yang mengungkapkan bahwa pemakai KB suntik yang hanya berisi progesteron bisa terjadi peningkatan 1-2 kg pada tahun pertama serta 4-10 kg setelah 3-5 tahun pemakaian kontrasepsi suntik. Teori Nault (2003) sejalan dengan penelitian yang dilakukan oleh Palimbo (2013) bahwa ada hubungan yang signifikan antara lama pemakaian $\mathrm{KB}$ suntik DMPA dengan peningkatan berat badan akseptor. Sedangkan penelitian yang dilakukan oleh Ekawati (2010) terdapat pengaruh KB suntik DMPA dengan peningkatan berat badan di Bidan Praktek Swasta (BPS) Siti Syamsiah Wonokorto Wonogiri, di dapatkan adanya pengaruh $\mathrm{KB}$ suntik DMPA dengan peningkatan berat badan. Penelitian Ekawati sejalan dengan penelitian Sriwahyuni (2010) mengenai hubungan jenis dan lama pemakaian KB suntik 3 bulan dengan peningkatan berat badan.

Pengaruh lama penggunaan $\mathrm{KB}$ suntik 3 bulan dengan kenaikan berat badan pada ibu pengguna $\mathrm{KB}$ suntik 3 bulan disebabkan adanya hormon progesterone yang 
terkandung dalam KB suntik 3 bulan yang menyebabkan bertambahnya nafsu makan pada ibu sehingga ibu lebih banyak makan dan mengalami kenaikan berat badan.

Hasil penelitian menunjukkan bahwa lebih banyak ibu pengguna KB suntik 3 bulan mengalami kenaikan berat badan dengan asupan kalori cukup sebesar 44 orang (80\%). Hal ini terjadi jika responden yang kebiasaan makan banyak dan berkali-kali tiap harinya sehingga saat menggunakan $\mathrm{KB}$ suntik DMPA (KB suntik 3 bulan ) maka frekuensi makan tersebut akan semakin bertambah karena adanya hormon progesteron yang terdapat dalam suntik DMPA dapat mengendalikan pusat nafsu makan di hipotalamus sehingga akseptor makan lebih sering dari biasanya. Jika hal ini tidak bisa dikontrol maka akan memperburuk keadaan khususnya kecepatan kenaikan berat badan (Palimbo dkk,2013).

Berdasarkan hasil uji fisher's exact test ada hubungan antara asupan kalori dengan kenaikan berat badan pada ibu pengguna KB suntik 3 bulan dikategorikan cukup kuat. Asupan kalori memberikan kostribusi terhadap kenaikan berat badan pada ibu pengguna KB suntik 3 bulan di wilayah kerja Puskesmas Pamboang Kecamatan Pamboang sebesar $18.7 \%$. Hal ini menunjukkan bahwa asupan kalori mempunyai peranan yang cukup besar terhadap kenaikan berat badan pada ibu pengguna KB suntik 3 bulan.

Nurahmah (2007), mengemukakan bahwa penanganan yang dilakukan untuk mengatasi atau mengurangi peningkatan berat badan adalah olahraga, mengonsumsi makanan yang berserat tinggi, mengurangi mengonsumsi makanan yang mengandung lemak, dan lebih banyak mengonsumsi makanan yang mengandung protein, dan perubahan perilaku dalam kebiasaan hidup sehari-hari.

Irianto (2014) berpendapat, kenaikan berat disebabkan karena hormon progesteron mempermudah perubahan karbohidrat dan gula menjadi lemak, sehingga lemak di bawah kulit bertambah. Asumsi peneliti, lebih banyak jumlah responden yang mengalami perubahan, ketika menggunakan kontrasepsi suntik, yang membuat porsi makan dari responden juga bertambah.

Peneliti menyimpulkan bahwa nafsu makan seseorang adalah besarnya frekuensi seseorang untuk mengkonsumsi makanan. Sistem pengontrol yang mengatur perilaku makanan terletak pada suatu bagian otak yang disebut hipotalamus. Hipotalamus mengandung banyak pembuluh darah, kemudian bertugas menggerakkan nafsu makan sehingga menyebabkan kenaikan berat badan akibat dari nafsu makan yang meningkat. Pengaruh asupan kalori dengan kenaikan berat badan pada ibu pengguna KB suntik 3 bulan disebabkan banyaknya asupan kalori yang dikonsumsi ibu sehingga mengalami kenaikan berat badan.

Hasil penelitian menunjukkan bahwa terdapat lebih banyak ibu pengguna KB suntik 3 bulan yang mengalami kenaikan berat badan dengan aktivitas fisik ringan sebesar $47(85,5 \%)$ dan yang tidak mengalami kenaikan berat badan dengan aktivitas fisik sedang sebesar 8 $(15,5 \%)$.

Berdasarkan hasil uji fisher's exact test tidak ada pengaruh antara aktivitas fisik dengan kenaikan berat badan pada ibu pengguna $\mathrm{KB}$ suntik 3 bulan dikategorikan lemah. Aktivitas fisik memberikan kontribusi terhadap kenaikan berat badan pada ibu pengguna $\mathrm{KB}$ suntik 3 bulan di wilayah kerja Puskesmas Pamboang Kecamatan Pamboang sebesar 7.67\%. Penelitian ini sejalan dengan penelitian Diana (2013) Dari hasil analisis menggunakan hasil uji fisher's exact test di dapatkan $\mathrm{p}=0,536$ dimana $\mathrm{p}$ lebih besar $\alpha=0,05$ H0 diterima $\mathrm{Ha}$ ditolak ini menunjukkan bahwa tidak ada penagaruh antara aktivitas fisik dengan kenaikan berat badan pada ibu pengguna KB suntik 3 bulan.

Namun, menurut Wijayanti (2006), bahwa aktivitas fisik dapat mempengaruhi 
peningkatkan berat badan seseorang. Hal ini disebabkan karena asupan energi yang melebihi kebutuhan tubuh yang biasanya dialami oleh orang yang kurang olah raga atau kurang aktivitas fisik sehingga energi yang masuk kedalam tubuh tidak dibakar atau digunakan yang kemudian disimpan dalam bentuk lemak sehingga menyebabkan berat badan naik.

Peneliti berpendapat bahwa pada ibu yang memiliki pekerjaan sebagai IRT dapat mengalami kenaikan berat badan karena lebih banyak menghabiskan waktu luangnya dirumah. Sehingga pengaruh hormon yang terkandung dalam DMPA yang menyebabkan peningkatan nafsu makan, menyimpan banyak karbohidrat dalam tubuh yang tidak dibakar. Kebiasaan makan atau kekenyangan mengakibatkan seseorang lebih mudah terserang rasa mengantuk, penurunan aktifitas fisik, dan waktu tidur yang lebih banyak.

\section{Kesimpulan Dan Saran}

Kesimpulan penelitian kenaikan berat badan pada ibu pengguna KB suntik 3 bulan di wilayah kerja Puskesmas Pamboang Kecamatan Pamboang Kabupaten Majene tahun 2016 adalah lama penggunaan merupakan faktor risiko terjadinya kenaikan berat badan, asupan kalori bukan merupakan faktor risiko terjadinya kenaikan berat badan pada ibu pengguna KB suntik 3 dan tidak ada pengaruh aktivitas fisik dengan kenaikan berat badan pada ibu pengguna KB suntik 3 bulan.

Penulis menyarankan kepada pemerintah/ puskesmas mengadakan penyuluhan kesehatan secara rutin dengan memasukkan materi tentang penyebab terjadinya kenaikan berat badan pada pengguna $\mathrm{KB}$ suntik 3 bulan. Bagi ibu pengguna KB suntik 3 bulan, sebaiknya sering berkonsultasi dengan petugas kesehatan.

\section{Daftar Pustaka}

Arnoli A dkk, 2015. Hubungan KB suntik 3 Bulan (DMPA) Dengan Kenaikan Berat Badan Di Puskesmas Cendrawasih Kota Makassar. (www.stikmakassar.ac.id)

Dinas Kesehatan Kabupaten Majene. 2014. Rekapitulasi data Gizi 2014

Everett.2007. Hubungan Kenaikan Berat Badan Dengan Penggunaan KB suntik 3 Bulan.

Erkadius dkk. 2013. Hubungan Antara Penggunaan Kontrasepsi Hormonal Suntik DMPA dengan Peningkatan Berat Badan Di Puskesmas Lapai kota Padang

Liando Hana dkk.2015. Faktor-Faktor yang berhubungan dengan Peningkatan Berat Badan Ibu Pengguna Alat Kontrasepsi Suntik DMPA(Depo Medroksi Progesteron Esetat)di puskesmas kumelembuai kabupaten minahasa.(ejournal.unsrat.ac.id/index .php/jkp/article/viewfile/8174)

Palimbo Adriana,Widodo Hariadi. 2013. Hubungan Pengguaan KB Suntik 3 bulan Dengan Kenaikan Berat Badan Pada Wanita akseptor KB Di Wilayah Kerja Puskesmas Lok Baintan. (akbid sari mulia.ac.id/ejurnal/download)

Puskesmas Pamboang (2016). Data akseptor $K B$ suntik 3 bulan

Purnamasari dian. 2009. Hubungan Lama Penggunaan $K B$ suntik (DMPA) Dengan Perubahan Berat Badan Di BPS YOSSI TRIHANA Jogonalan Klaten.

(https://digilib.uns.ac.id/...=/Pengaruh -KB-suntik-DMPA-terhadap-

peningkatan-berat badan)

Purwanti.2002. Kenaikan Berat Badan

Putri. 2014. Pengaruh Lama Penggunaan KB Suntik 3 Bulan.

Riskesdas. 2013. Penggunaan Alat Kontrasepsi

Sari Nofria. 2013. Hubungan Penggunaan Suntik 3 Bulan dengan Kenaikan 
Berat Badan Pada Akseptor KB di Kelurahan Darok Tipo Wilayah Kerja Puskesmas Guguk Panjang Bukit Tinggi.

Suratun. 2008. Pengaruh Penggunaan KB Suntik 3 Bulan

Suryani Evi Sri dkk. 2010. Pengaruh Lamanya Penggunaan Kontrasepsi (DMPA) terhadap Kenaikan Berat Badan di BPS Supriyatni Desa Paketingan Kecamatan Sampang Kabupaten Cilacap

Wahab, A. 2013. Pengantar Riset. Edisi Pertama. Yogyakarta: Kaukaba Dipantara

Wahyuni Sri. 2010. Pengaruh Penggunaan KB Suntik 3 Bulan

Wijayanti. 2006. Pengaruh Aktivitas Fisik dengan Kenaikan Berat Badan

Wibawa. 2013. Kenaikan Berat Badan terhadap Ibu Pengguna KB Suntik 3 Bulan 